\title{
INSTITUTIONALIZING CULTURAL FUNDING AT THE LEVEL OF THE LOCAL GOVERNMENT IN THE PHILIPPINES
}

\author{
Gina S. Salazar \\ Department of Arts and Communication College of Arts and Sciences \\ University of the Philippines Manila \\ gssalazar@up.edu.ph
}

\begin{abstract}
The major purpose of the study is to outline how the institutionalization of funding for Culture and the Arts could be operationalized at the Local Government Units (LGUs) in the Philippines to facilitate the sustainability of cultural programs in Philippine localities. More specifically, this study aims to discuss the status of cultural funding in the Philippines and the challenges that beset the LGUs in operationalizing cultural funding at their level. Using the qualitative approach, the study proceeds with the analysis of the status of cultural funding in the Philippines; data are derived by the researcher as a participant-observer during a national training on Culture-based governance participated in by executives and tourism officers from Philippine LGUs. Gender- Responsive Budgeting is presented as a case of an institutionalized mechanism for financing gender concerns in the country, an illustration of the possibility of implementing institutionalized funding for Culture and the Arts at the level of the LGUs. The operationalization of the institutionalization of cultural funding is then outlined; challenges associated with the process of institutionalizing Culture and the Arts funds are analyzed using Thomas Schmitt's general framework for the analysis of fields of governance; and recommendations are made as to how these challenges are to be confronted by the LGUs. The institutionalization of cultural funding can only be ultimately realized for the LGUs via a Republic Act. A requisite external to institutionalization is the process of reforming mindsets in understanding Culture and its role in human development; and in shifting existing beliefs to the idea that effective Cultural Governance is equivalent to institutionalizing cultural funding at the Philippine LGUs.
\end{abstract}

Keywords: Cultural Funding, Institutionalization, Funds for Culture, Philippine Local Government, Local

\section{Government Funding}

\section{Introduction}

The discourse on cultural funding in the Philippines could be situated in the broader context of human development. This is in recognition of the view of Culture as 'the solid fourth pillar in sustainable development' [1]. The issue has to do with the lack of the specificity of budget allocation for cultural programs which results in the need for funding for Culture and the Arts at the level of the LGUs (provincial governments, cities, or municipalities) in the country. The challenge then is how to implement effective Cultural Governance in the form of sustainable income-generating cultural programs in the local communities that would allow community-based artists to achieve socioeconomic growth for themselves and the rest of the communities. The institutionalization ${ }^{1}$ of cultural funding at the LGU level is a way to effective Cultural Governance.

The global context of the issue of cultural funding has been brought out in the 'Agenda 21 for Culture'. The presumption is that in acknowledging the 'renewed importance of Culture', local governments must be committed to the achievement of cultural development via cultural programs and budgets [2].

Locally, there exists a constitutional mandate for Culture. Section 15, Article XIV of The 1987 Constitution of the Republic of the Philippines in

\footnotetext{
${ }^{1}$ This is defined by Huntington as 'the process by which organizations acquire value and stability' (1968, p.12).
} 
its online version states that 'Arts and letters should enjoy the patronage of the State. The State shall conserve, promote, and popularize the nation's historical and cultural heritage and resources, as well as artistic creations' [3]. There are also 'Allocations for Education, Culture \& Sports/Manpower Development' as indicated in the Statement of Income and Expenditures (SIE) Manual of the Bureau of Local Government Finance (BLGF) [4]. These allocations are specifically for the improvement of school facilities, for manpower development, for sports, and for 'cultural preservation and enrichment' [5].

Given that cultural funding is a 'glocal' [6] concern, it becomes imperative to discover means by which funding for Culture and the Arts at the level of the Philippine LGUs could be permanently reinstated for sustained income-generating community-based cultural programs. The major purpose of the study is to outline how the institutionalization of funding for Culture and the Arts could be operationalized at the LGUs in the Philippines to facilitate sustained community-based cultural activities that can be sources of livelihood not only for the local artists but for the other members of the localities as well. The specific aims are to (1) discuss the status of Philippine cultural funding; (2) examine the challenges that beset the LGUs in the process of operationalizing cultural funding at their level; and (3) make recommendations to address the challenges.

The significance of the study is two-fold. In the area of Public Administration, having the means for an institutionalized cultural funding is equivalent to strengthening and stabilizing cultural programs in the LGUs. As Gera (2008) states: '...to operationalize the notion of institutionalization, the main attribute that is easily measured across polities is stability' [7]. There will be accountability and transparency in decisionmaking relating to cultural planning. A credible government policy commitment to promoting Culture would be in place.

In terms of development, the institutionalization of cultural funding will be instrumental in achieving national development as sustained cultural programs are definite means to make the Filipinos discover their cultural identity. Sectoral development would also take place with sustained income-generating cultural activities in the localities. With these programs as constant sources of livelihood for community-based artists, the cultural sector could engage in participating in economic growth in their areas; this is the realization of an opportunity for sustainable human development.

\section{Literature Review}

The Policy Department of the European Union (2006) reports the sources of cultural funding of its member-countries [8]. The examination of the cases of the sources of cultural funds of Poland and Germany is useful to the Philippines given that all three have the local-level government as governmental structure; that whatever funding resourcing works for the two countries may also do for the Philippines. Poland makes use of its local government taxing authority with what it calls the ' $1 \%$ Percentage Legislation at the Municipal Level'. In this mechanism for sourcing cultural funds, every citizen in Poland allots $1 \%$ of his or her salary to a chosen cultural group or sector [9].

Germany, on the other hand, through publicprivate partnership, utilizes the ' $1 \%$ Rule.' In this set-up, $1 \%$ of the cost of the construction of any building is allocated to the cultural design of that building [10].

Both countries also finance culture with lottery funds, with Germany prioritizing the support for artists; and Poland focusing on the support for education.

In the Philippines, ' $82 \%$ of the LGUs surveyed do create allocations for cultural activities' [11]. However, these allocations do not ensure the sustained planning and implementation of programs responsive to the specific requirements as set by the Culture and the Arts for communitybased artists due to the lack of a mandated cultural funding.

The present study draws on the reality presented by Campomanes and Virtucio (2004) and continues with the analysis of the state of cultural funding in the Philippines using Thomas Schmitt's (2011) general framework for fields of governance, focusing on Cultural Governance. Also adopted are the concepts intrinsic, instrumental and institutional values of Culture (Holden \& Balta, 2012).

This descriptive and exploratory study proceeds with the description of the status of cultural funding in the Philippines. Aside from existing literature and documents, data are derived by the researcher as a participant-observer during a national training on Culture-based Governance participated in by executives and tourism officers from Philippine LGUs. A budget officer has been interviewed for additional data on the process of generating funds for cultural programs at the local government level. Gender-Responsive Budgeting is then presented as a case of an institutionalized mechanism for financing gender concerns at LGUs in the country. This is an illustration of the possibility of implementing institutionalized funding for Culture and the Arts at the LGU level. 
The operationalization of the institutionalization of cultural funding is then outlined using the data sources previously mentioned. The challenges associated with the process of institutionalizing Culture and the Arts funds are analyzed using Schmitt's general framework for the analysis of fields of governance. Recommendations are made as to how these challenges are to be confronted by the LGUs.

\section{Discussion}

At the national level, there are agencies responsible for the promotion and conservation of Culture in the Philippines.

The National Commission for Culture and the Arts (NCCA) is created through Republic Act No. 7356. It is a national agency in charge of the 'protection and conservation of the national cultural heritage' (as stated in Republic Act No. 10066). The NCCA receives funding via The National Endowment Fund for Culture and the Arts (NEFCA) [12].

The Cultural Center of the Philippines (CCP), 'the national center for the performing arts' [13], has its origin in Presidential Decree No. 15 [14]. Section 11 of the same Presidential Decree provides that CCP would derive its funds from the ' $5 \%$ of the total annual collections of all taxes on amusements'. Section 47 of the National Cultural Heritage Funding, on the other hand, provides an appropriation for culture in the amount of $\mathrm{P}$ $100,000,000.00$ [15].

As a supporting legislation, Republic Act No. 10066 provides 'for the Protection and Conservation of the National Cultural Heritage, Strengthening the National Commission for Culture and the Arts (NCCA) and Its Affiliated Cultural Agencies, and for Other Purposes.' Section 47 of the same republic act states that the National Cultural Heritage funding appropriation amounting to $\mathrm{PhP} 100 \mathrm{M}$ would come from the National Treasury [16].

At the level of the LGUs, cultural funding is facilitated through a regular ordinance accompanied by an appropriation ordinance. The Annual Investment Plan in the Short-term Development Plan of the LGUs, along with the Multi-sectoral Development Plan, is another possible source of cultural funds . Funding could also be channeled through Account 200-Grants and contributions, aids to cultural programswhich is included in the expenditure component of the budget. Cultural funding could be included in the Executive agenda as well. Aside from ordinances and resolutions, memoranda from city directors to barangay captains could be conduits for fund allocation

(D. Lopez, personal communication, October 6, 2014).

Cultural funding is institutionalized only at the level of the national cultural agencies via legislation. The operationalization of the institutionalization of cultural funding at this level is top-down.

Although LGUs can be beneficiaries of the cultural programs of national agencies, these instances are not on a regular permanent basis. As for the LGUs, executives have to be 'very creative in looking for cultural funding' (Participants in the National Training on Culture-based Governance, communication, October 7, 2014).

The Gender and Development (GAD) Budget Law, a funding institutionalization mechanism enacted during the term of President Fidel V. Ramos aims 'to incorporate gender in the mainstream budget process of policy formulation and implementation...' It stipulates that '... a minimum of $5 \%$ of all agency budgets must go down to women and development' [17]. GAD Budgeting demonstrates the possibility of institutionalizing Cultural funds at the Philippine LGUs. The following are the supporting legislation for GAD:

1) Republic Act 7192 of 1992 or The Women in Development and Nation Building Act;

2) Executive Order No. 273 of 1995 Approving and Adopting the Philippine Plan for Gender-responsive Development;

3) 1995 General Appropriations Act (GAA);

4) Joint Memorandum Circular 2004-1 'Guidelines for the Preparation of GAD Plan and Budget and Accomplishment Report to Implement the Section on Programs/Projects Related to GAD of the General Appropriations Act (GAA) by the Department of Interior and Local Government (DILG), Department of Budget (DBM), and the National Commission on the Role of Filipino Women (NCRFW)

5) Joint Memorandum Circular 2007-1 'Guidelines for Gender and Development (GAD) Planning, Programming and Budgeting, Implementation and Monitoring by the DILG, DBM, NEDA, and NCRFW) [18]. 
The Quezon City GAD Code is an illustration of the implementation of GAD Budgeting at the local government level. This is made possible through Ordinance No. SP-1401, S-4004 'An Ordinance providing for a city gender and development code and for other purposes' [19].

The operationalization of cultural funding can follow the top-down process via legislation. This is a tedious and long process that initially begins with the search for Congress legislator lobbyists.

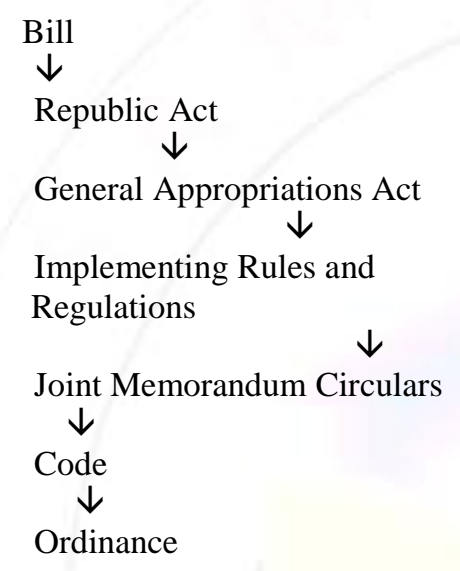

Fig.1 Top-down institutionalization of cultural funding

The bill is the appropriate measure to take since the issue has to do with budget appropriation of the government [20] for the arts.

Given the list of taxes that the local government can impose for collection as indicated in the Philippine Administrative Code of 1987, culture funds could possibly be derived from the amusement tax collection of the provincial governments. This amendment could be effected by specifying a particular percentage of the said tax to be allocated to cultural funding. The amendment could further specify the direct transfer of the funds from the provincial government to the cities and municipalities who would have the function of planning and implementing cultural programs.

Aside from the challenge posed by the time element in completing the process of transforming a bill on cultural funding into a law, there is the challenge of reforming mindsets and paradigms in the LGUs' understanding of Culture and its role in human development. The LGUs interchange tourism, culture, and the arts; worse, '... notions of culture range from staging beauty contests to inventing a fiesta...or from launching art contests...to the maintenance of museum or a library as mere infrastructure [21]. Culture and the Arts are also treated as entertainment [22].
On the part of the executives of LGUs, there exists the challenge of understanding that effective Cultural Governance is achievable through the institutionalization of funds for Culture and the Arts. Their leadership priorities must be redirected towards cultural policy priorities.

In the aspect of the structural organization in the Philippine local government, the perception by LGUs that cultural programs can be accommodated by tourism officers and offices [23] has to be corrected. It is the ideal that cultural workers are made to plan and implement these programs since their knowledge and experience would contribute to the relevance and responsiveness of such programs to the specific cultural needs of the communities. A related issue is the 'absence of full-time [cultural] workers under a plantilla' [24]. Items for cultural workers need to be in place. This would ensure the sustainability of manpower support for the planning and implementation of community-based cultural programs.

The case of the cultural funding in the Philippines is grounded on the issue of the priority given by LGUs to Culture and cultural programs. Community-based cultural groups experience the lack of a sustained financial support from the LGUs (J. Cristobal, personal communication, August 28, 2014). There are laws pertaining to the promotion and preservation of Culture but these are not pertinent to budget allocations. The list of functions of LGUs does not include functions relating to Culture and funding for it. There is a conflictive relationship between the community artists and the LGUs on the issue of cultural financing. The LGUs still adhere to a culture of dogmatic orientation to rules and budgetary discretion. It is hoped that with the negotiation between parties, sustainable income-generating cultural programs could be planned and implemented.

Meeting the challenges previously mentioned is difficult. But attending Culture-based governance trainings, similar to those conducted by the National Commission on Culture and the Arts of which the writer is a part, should be a good start in deepening the LGU executives and legislators' understanding of Culture and its instrumentality in human development. With these trainings, LGUs would be made to realize that Cultural Governance is most effective if there is a permanent and constant source of funding for cultural programs.

Tourism offices in LGUs must be distinct from cultural offices. Aside from the difference in competencies required by each agency, there is a significant difference in the valuation attributed to 
Culture, which may be intrinsic, instrumental, and institutional [25]. Tourism offices focus on the instrumental value of Culture; that is, funding is allocated to Culture because of its economic and social returns. Cultural offices, on the other hand, attribute all three valuation to Culture. The community-based cultural workers would incorporate in their planning and implementation of cultural programs the mindset that cultural activities are valuable goods in themselves (intrinsic value of Culture). The aspect of creating sustainable income-generating cultural activities for artists and the rest of the communities is a part of the instrumental value of Culture. The institutional value of Culture, on the other hand, is to be exercised in the manner by which cultural programs are better designed and implemented not just for the community of artists but for the public in general.

Although the institutionalization of funding could only take place with a legislation, LGUs can already put in place ordinances and corresponding appropriation ordinances for cultural programs. This is the only way to secure institutional financial support for Culture and the Arts at the level of the LGUs while awaiting legislation.

Another necessary step that is related and is a requisite to the operationalization of the institutionalization of cultural funding at the LGUs is to amend the list of functions of the LGUs in the Philippine Administrative Code of 1987 to include cultural planning and implementation.

\section{Conclusion}

The institutionalization of cultural funding is an issue at the level of the Philippine LGUs that can primarily be addressed through a top-down approach to legislation. The possibility of this process has been illustrated in the case of the GAD Budget. The toughest challenge in the process of institutionalizing cultural funding is reforming the mindsets of LGU executives and legislators, particularly reorienting them to the concepts of Culture and effective Cultural Governance. This would eventually lead to the prioritization of cultural programs by the LGUs. The availability of items for cultural workers in the cities and municipalities is another hurdle. Finally, the drafting of ordinances and appropriation ordinances at the LGUs would serve the purpose of cultural funding institutionalization as the legislation for Culture and the Arts funds is awaited.

The possible ways of addressing the issue on the institutionalization of LGU cultural funding include the attendance by LGU executives and legislators at culture-based governance trainings; the establishment of cultural offices distinct from tourism offices in LGUs; the creation of an ordinance and its corresponding appropriation ordinance as immediate forms of legislation at the level of the LGUs; the inclusion of cultural planning and implementation in the list of LGU functions; and ultimately, the legislation of cultural funding via a Republic Act. Nothing is difficult or impossible with political will.

\section{References}

[1] J. Pascual, "Cultural Policies, Human Development and Institutional Innovation: Or Why We Need an Agenda 21 for Culture," Retrieved from http://www.culturalpolicies.net

[2] J. Pascual, "Cultural Policies, Human Development and Institutional Innovation: Or Why We Need an Agenda 21 for Culture," Retrieved from http://www.culturalpolicies.net

[3] The Official Gazette, Retrieved from http://www.gov.ph

\section{[4] http://www.bigf.gov.ph}

[5] http://www.nscb.gov.ph

[6] G. Campomanes, and M.A. Virtucio, Culture \& Governance, Pasig City: Development Academy of the Philippines, 2004.

[7] W. Gera, "Institutionalization in Philippine Decentralization: Rethinking the Bureaucratic Imperative", Retrieved from http://www.unpan1.un.org

[8] Policy Department, European Union, "Financing the Arts and Culture in the European Union, 2006, Retrieved from http://www.culturalpolicies.net.

[9] Policy Department, European Union, "Financing the Arts and Culture in the European Union, 2006, Retrieved from http://www.culturalpolicies.net.

[10] Policy Department, European Union, "Financing the Arts and Culture in the European Union, 2006, Retrieved from http://www.culturalpolicies.net.

[11] G. Campomanes, and M.A. Virtucio, Culture \& Governance, Pasig City: Development Academy of the Philippines, 2004.

[12] http://www.ncca.gov.ph

[13] http://www.ncca.gov.ph

[14] http://www.lawphil.net

[15] http://www.heritage.org.ph

[16] http://www.heritage.org.ph

[17] L. Briones, and G. Valdez, "Institutionalizing Genderresponsive Budgeting in the Philippines: The Beginning, Retrieved from http://www.gender.budgets.org .

[18] http://www.editorialexpress.com

[19] http://www.editorialexpress.com

[20] http://www.senate.gov.ph

[21] G. Campomanes, and M.A. Virtucio, Culture \& Governance, Pasig City: Development Academy of the Philippines, 2004. 
[22] G. Campomanes, and M.A. Virtucio, Culture \& Governance, Pasig City: Development Academy of the Philippines, 2004.

[23] G. Campomanes, and M.A. Virtucio, Culture \& Governance, Pasig City: Development Academy of the Philippines, 2004.
[24] G. Campomanes, and M.A. Virtucio, Culture \& Governance, Pasig City: Development Academy of the Philippines, 2004.

[25] J. Holden, and J. Balta, "The Public Value of Culture: a literature review, Retrieved from http://www.eence.info . 